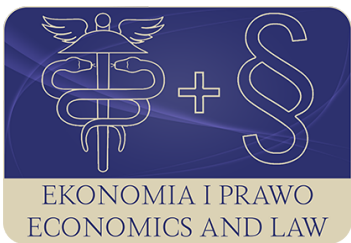

EKONOMIA I PRAWO. ECONOMICS AND LAW

Volume 18, Issue 2, June 2019

p-ISSN 1898-2255, e-ISSN 2392-1625

www.economicsandlaw.pl

ORIGINAL ARTICLE

received 02.07.2018; revised 20.01.2019; accepted 30.06.2019

Citation: Gorączkowska, J., \& Tomaszewski, M. (2019). Support of innovation activity in small and medium-sized enterprises in the Greater Poland Voivodeship. Ekonomia i Prawo. Economics and Law, 18(2): 183-195. doi:10.12775/EiP.2019.014.

\title{
Support of innovation activity in small and medium-sized enterprises in the Greater Poland Voivodeship
}

\author{
JADWIGA GORĄCZKOWSKA \\ corresponding author \\ University of Zielona Góra, Faculty of Economics and Management, Department of Innovation \\ and Entrepreneurship, ul. Podgórna 50, 65-246 Zielona Góra, Poland \\ $\square$ j.goraczkowska@wez.uz.zgora.pl \\ (D) orcid.org/0000-0001-6394-463X \\ MAREK TOMASZEWSKI \\ WSB University in Poznań, Faculty of Economics in Szczecin, Poland \\ $\square$ mtomaszewski@wsb.szczecin.pl \\ (D) orcid.org/0000-0003-2590-5159
}

\begin{abstract}
Motivation: Small and medium-sized enterprises, due to their large number, play an important role in the development of the Polish economy. Therefore, the focus should be on creating the right frameworks for their functioning - they should allow them to develop and stimulate the implementation of innovative solutions. Business support organizations (BSOs) are one of the entities that can facilitate development ant stimulation. The main types of BSOs in Poland are: technological parks and incubators, academic business incubators, centers for technology transfer, business angels networks, local/regional load funds, credit guarantee funds, and training and consulting centers. These entities should contribute to the implementation of new solutions in the surveyed enterprises and improve their competitive position.

Aim: The aim of the article is to identify impact of business support organization on the innovation activity in industrial enterprises in the Greater Poland Voivodeship. The research hypothesis is the claim that BSOs increase the odds of implementation of new products and process in enterprises, but their impact will be different. The hypothesis will be validated on a sample of 442 small and medium-sized, manufacturing companies,
\end{abstract}


which are located in Greater Poland Voivodeship. To carry out the study a multi-factor logit regression method will be used.

Results: The research hypothesis is confirmed - BSOs increase the chances on innovation activity but their influence is different. Most effective are training and consulting centers and financing organizations, but this institution stimulate the implementation of new products and processes on the scale of the enterprise and innovation centers (technology parks, academic business incubators and technology transfer offices) of the country.

Keywords: innovation; support; small and medium-sized enterprises; technology parks; technology transfer offices; business support organizations

JEL: O31; O32; L60

\section{Introduction}

In Poland, in manufacturing, small and medium-sized enterprises (SMEs) account for $95.00 \%$ of all entities (GUS, 2017, p. 52), however their level of innovation is significantly smaller than that of large enterprises. The share of net revenues from sales of innovative products in net revenues from total sales in small enterprises was $1.71 \%$ in small enterprises, $4.95 \%$ in medium-sized enterprises, and over $10.00 \%$ in large ones ${ }^{1}$. This fact illustrates that SMEs are struggling with significant problems related to the impression of new solutions, and at the same time, due to their large number, it can be assumed that they have a significant impact on the development of the Polish economy. Therefore, the focus should be on creating the right framework of functioning for them they should allow them to develop and stimulate the implementation of innovative solutions. One of the entities that can facilitate this are business support institutions. These are entities that, acting on a commercial and/or non-profit basis, should stimulate the innovation of entities that would have problems with implementing novelties themselves. In this context, the purpose of the study presented in the article is to determine the impact of business support institutions on small and medium-sized enterprises. However, the research hypothesis is that support institutions will stimulate innovative activity of SMEs, but their impact will be diversified. This is related, for example, to the specificity of services provided by individual support institutions. The aim of the article is to identify impact of business support organization on the innovation activity in industrial enterprises in the Greater Poland Voivodeship.

\section{Literature review}

The problems that small and medium entrepreneurs are facing with regard to innovation activity are of different nature. They may relate to knowledge, market, costs, etc. (OECD \& Eurostat, 2005, pp. 117-118). Some of them should be able to compensate for business support institutions. In the subject literature, they

\footnotetext{
${ }^{1}$ Data taken from the Local Data Bank (2018).
} 
are defined on the basis of the functions they perform in the economy (Matusiak, 2011, p. 182):

- innovation centres - are aimed at broad promotion and incubation of innovative entrepreneurship, technology transfer and provision of pro-innovation services, activation of academic entrepreneurship and cooperation between science and business; these include technology parks, technology incubators, technology transfer offices and academic business incubators;

- shadow banking financial institutions - their aim is to limit financial discrimination of newly created and small companies without a credit history, providing financial services adapter to the specifics of new business ventures; in Poland there are networks of business angels, local/regional loan funds and credit guarantee funds;

- entrepreneurship centres - their task is to broadly promote and incubate entrepreneurship (often in discriminated groups), provide support services to small companies and activate the development of peripheral regions or those affected by the structural crisis; this group includes training and consulting centres.

The presented division clearly indicates the specifics of business support institutions in Poland. In the first group of entities, the greatest emphasis is placed on innovative activity. Technological parks are a territorially separate unit in which enterprises and research centres are located. Research shows that the close geographical proximity of these entities means that they cooperate more frequently with each other (Rocio Vasquez-Urriago et al., 2016, pp. 137147). It is thanks to the knowledge provided by universities that the innovative capacity of tenant companies in parks improves (Diez-Vial \& Montoro-Sanchez, 2016, pp. 41-52). As part of parks or separate institutions, there are technology incubators or academic business incubators. They support newly established enterprises (in the start-up phase) in the first years of operation on the market. Operation within the incubator structures allows young entrepreneurs to create business networks and stimulate their dynamic progress (Stokan et al., 2015, pp. 317-327). Technology transfer centres play an important role in the process of creating innovation (Barra \& Zotti, 2018, pp. 432-457). They increase the chances of creating inventions by the universities and are examples of good practices that are readily imitated by other universities (Castillo et al., 2018, pp. 120-138).

Business angel networks include private investors who capitalize innovative enterprises in exchange for shares in these entities. An association in the network allows to offset the risk related to venture capital investments (Makarevich, 2018, pp. 153-165). In Poland, the business angels network market is still underdeveloped. Loan funds and credit guarantee funds are more popular. These institutions provide capital and guarantee loans on preferential terms to entities that are not able to obtain them on a commercial basis. The borrowed amounts are usually small (up to PLN 120,000/around EUR 30,000), which makes it 
difficult to finance innovative projects as a whole (Pietras \& Głodek, 2011, p. 35), but may be a contribution to their commencement.

Training and consulting centres constitute the largest group of business support institutions in Poland. They provide services that aim to improve the level of development of the region in which they operate and improve the quality of life of local communities (Koprowska-Sklalska, 2010, p. 143). Centres, due to their number, are often the first link in the search for support for innovation.

When looking at the research on support for innovation and entrepreneurship, it can be stated that business environment institutions should contribute in a wide way to increasing the innovation of enterprises. Analyses carried out for the purposes of this article will allow this assumption to be verified.

\section{Method}

Dependent variables illustrating the impact of business support institutions on the innovative activity of small and medium enterprises were adopted in accordance with international standards for measuring and assessing innovative activity contained in the Oslo methodology. These include:

- expenses for innovative activity - expenditures incurred on research and development activities, investments in new fixed assets (buildings, premises and lands, as well as machine park of enterprises) and expenses related to the purchase of new computer software; all the mentioned types of expenses should be related to the implementation of product and process innovations in the enterprise (OECD \& Eurostat, 2005, pp. 92-93);

- implementation of product and process innovations, including new production methods, production and business support systems (OECD \& Eurostat, 2005, pp. 48-49). In addition, the analyses take into account the degree of novelty of the implemented innovations in the context of the enterprise, market, country and world.

Support institutions, which are most common in Poland, i.e. technology parks, technology incubators, academic business incubators, technology transfer offices, business angel networks, local/regional loan funds, credit guarantee funds and training and consulting centres have been adopted as independent variables.

The variables accepted for the study were dichotomous in nature. This means that if the enterprise used, for example, technology park services, its responses on the questionnaire form were assigned 1 , and if not -0 . The zero-one variables allow for the use of logit modelling in analyses. The logistic function assumes values from 0 to 1 , so it can describe probability values that always fall within this range (Stanisz, 2007, p. 219). In the case of the conducted research, they will determine the chances of the occurrence of innovative activity in the surveyed enterprises. Generally speaking, logistic regression is a mathematical model that we can use to describe the influence of several variables $X_{1}, X_{2}, \ldots, X_{k}$ on the dichotomous variable $Y$. When all independent variables are qualitative, 
the logistic regression model is synonymous with the log-linear model (Świadek, 2011, p. 102).

The maximum likelihood estimation (MLE) is used to estimate the parameters of models with the dichotomous variable. It is based on the fact that a parameter vector is sought $\alpha_{(k)}^{M L}$, which guarantees the highest probability of obtaining the values observed in the sample (Welfe, 2008, p. 73). Maximization of the credibility function is performed using techniques used in non-linear estimation (Maddala, 2001, p. 73).

In the logit models, the odds are an important measure of determining the probability. The odds are understood as the ratio of the probability that a given phenomenon will occur to the probability that a given phenomenon will not occur (Danieluk 2010, p. 206). In the conducted study, two groups of enterprises are compared with each other - those that used the services of one or several analysed support institutions and those that did not do it. Therefore, one can compare the odds ratio of two classes of observation. The odds ratio indicates the relationship that a given event (e.g. establishing cooperation with suppliers) will be in the first group of elements (e.g. in enterprises using technology park services) in relation to the fact that it will also be in the second group (e.g. in the group entities that did not use the services of parks). They take the form of the formula (1) (Stanisz, 2007, p. 221):

$$
\text { OddsRatio }=\frac{p_{1}}{l-p_{1}} \frac{1-p_{2}}{p_{2}}=\frac{p_{1}\left(l-p_{2}\right)}{p_{2}\left(l-p_{1}\right)}
$$

The values of odds ratio are interpreter as follows:

- OddsRatio $>1$ - in the first group the incident is more likely to occur;

- OddsRatio $<1$ - in the first group the incident is less likely to occur;

- OddsRatio $=1$ - in both observation classes, the incident is just as likely to occur.

The article presents the values of odds ratios that meet the conditions of statistical significance.

\section{Results}

In the study of the impact of business support organisations on the innovative activity of small and medium-sized enterprises, 442 enterprises from the Greater Poland voivodeship participated, whose business profile corresponds to section $\mathrm{C}$ of the Polish Classification of Activities 'Industrial processing'. Over half of them used low production technique (51.8\% of enterprises). Medium-low technology was used by nearly $30.0 \%$ of enterprises, and medium-high by over $17.0 \%$. High technology was used in less than $1.0 \%$ of the surveyed entities.

From among all business support organisations whose services were used by the surveyed entrepreneurs, training and consulting centres enjoyed the greatest popularity, with which over $1 / 3$ of the surveyed enterprises cooperated. 1/5 
of entities searched for sources of financing in local and regional loan funds and loan guarantee funds. $10.0 \%$ of the surveyed enterprises cooperated with technology parks. The remaining support centres were characterized by a much smaller number of service recipients - less than $5.0 \%$ of enterprises used technology incubators, technology transfer offices and business angel networks by around $4.0 \%$, and academic business incubators by $2.5 \%$. When it comes to the use of business support organizations the percentage shares do not sum to $100.0 \%$, because not all of the surveyed businesses cooperated with support institutions (table 1).

Taking into account the expenditure borne for research and development in small and medium-sized enterprises, academic incubators of entrepreneurship had the greatest impact on them. Their clients have been incurring them almost nine time more often. However, more than two-fold increase in opportunities was noted in entities that cooperated with technology incubators, loan funds and technology parks, and nearly two times among service recipients of training and consulting centres. Other support organisations did not play a significant role in this area. The constant indicates that the total chances of incurring expenditure on R\&D activities in them are nearly $70.0 \%$ lower than in enterprises that did not use the services of technology transfer offices, business angel networks and credit guarantee funds.

Odds for investments in new fixed assets (in total) were increased by the training and consulting centres almost four times, and twice by the loan funds. Also the other support organisations in total increased the odds for this type of investments over two times. Taking into consideration particular types of investments, in entities that used the services of training and consulting centres, the odds for investments in new fixed assets increased over 2.5 times. Other centres did not play any role in this area. Customers of support organisations invested in machinery park much more often. This type of expenditure appeared twice as often in entities that used the services of technology parks, training and consulting centres and guarantee funds. Also other support organisations in total increased the odds for this type of investment by $50.0 \%$.

New computer software was purchased three Times more often in entities that cooperated with technology parks and nearly twice as often among service recipients of training and consulting centres (table 2).

Product innovations were more than twice as frequently implemented in entities that used the services of loan funds and technology parks. Other organisations also played a role in this area - thanks to their activity, entrepreneurs implemented new products 1.6 times more often than entities that did not use their services.

Business support organisations more often initiated the implementation of process innovations. In their case, odds ratios were higher than for product innovations. The odds of implementing new processes in entities that guaranteed loans and credits in loan funds and used the services of training and consulting centres increased almost four times. A threefold increase in odds was 
noted in the case of cooperation of enterprises with technology parks and loan funds, while other organisations increased them by over $40.0 \%$. When looking at particular types of processes, it is noted that the technology transfer offices and loan funds increased the odds for implementing new production methods into enterprises almost three times, guarantee funds over two times, and training and consulting centres almost two times. The new by-production systems were implemented 2.5 times more frequently thanks to the activity of the business angel networks, more than twice thanks to the activity of guarantee funds, and almost twice thanks to training and consulting centres. Systems supporting business operations were more often implemented in entities that used technology incubators (more than 5 times), technology parks (more than 3 times) and loan and guarantee funds as well as training and consulting centres (nearly 2 times). Other support organisations did not play any role in this area (table 3 ).

In enterprises that used loan fund services, the odds of implementing new product innovations for the enterprise were almost twice as high as in entities that did not. Guarantee funds and training and consulting centres increased them more than 1.5 times. Entrepreneurs, thanks to the activity of academic business incubators more than 4 times more often, and technology parks more than twice as often, implemented innovations on the national scale (table 4).

Process innovations, which are new to the enterprise implementing them, were more than twice as often implemented in entities that used the services of loan and guarantee funds as well as training and consulting centres. On the other hand, national innovations were four times more frequently implemented in entities that cooperated with academic business incubators and technology transfer offices. In the case of process innovations implemented as a novelty on the national scale, for the first time an individual odds ratio appeared below one. It concerned credit guarantee funds and indicates that entrepreneurs who use their services have a $65.0 \%$ lower odds of implementing such innovations than entities that do not use these services (table 5).

\section{Conclusion}

The analysis of the impact of business support organizations on the innovative activity of small and medium-sized enterprises in the Greater Poland voivodeship provided interesting conclusions on the functioning of the surveyed entities.

In the surveyed region, training and consulting centres played a significant role. The odds ratio estimated for them met the statistical significance conditions in almost all of the analysed models. Their services were also used by the largest number of enterprises, hence the conclusion that these organisations play an important role in stimulating the innovation of small and medium enterprises in the region.

Regional/local loan funds and credit guarantee funds were also significant. They contributed to the implementation of product and process innovations 
and to a small extent to conducting $R \& D$ works and investments in new fixed assets.

For the innovation centres, a smaller number of odds quotas meeting the conditions of statistical significance was estimated than in the case of funds and training and consulting centres. Fewer enterprises also used their services. However, it should be emphasized that the quotients were of great value. This shows that their effectiveness is high, but they affect a smaller number of enterprises.

Taking into account the scale of new innovations implemented, it can be noticed that despite the fact that entrepreneurs implemented all kinds of innovations in the region, business support organisations significantly influenced the implementation of new products on the scale of the enterprise and the country. The first type was stimulated by training and consulting centres as well as loan and guarantee funds, and the second by innovation centres: technology parks, academic business incubators and technology transfer offices.

Combining the conclusions that have arisen after the analysis of individual tables, it is noted that innovation centres contribute to the implementation of new products, the scale of which is greater than the innovations stimulated by funding organisations and training and consulting centres. In this context, it can be argued that smaller financial resources (provided by the funds) constitute sufficient capital to implement innovations with a smaller spectrum of novelty. In the case of country-wide novelties, the funding organisations no longer play such an important role (the value of the odds below one in the case of guarantee funds even indicates the lack of their positive impact), whereas innovation centres play a role. It can be concluded that a larger scale of novelty entails the need for higher capital investments than the amount of loans that funds are able to provide.

For the innovation centres, a smaller number of quotients were estimated that met the conditions of static significance than in the case of funds and training and consulting centres. This does not mean that these organisations do not play a role in the region. It is possible that due to the fact that their services were used by a small number of entities, they did not reach critical mass that would allow systemic impact on the innovation of the entities studied. However, their role is significant because despite a small number of service recipients, they have raised their odds of experiencing new products several times. It is worth noting that the majority of surveyed entities (which is in line with the industry structure in the voivodeship) used a low manufacturing technique. It could have caused that innovation centres did not have an area in which they could stimulate innovation in these entities and hence their weaker impact on the regional industrial system.

In the light of the above conclusions, it can be assumed that the research hypothesis at the beginning of the article has been confirmed - business support organisations stimulate the innovation of small and medium-sized enterprises. It is noted that innovation centres have a more difficult task - a smaller num- 
ber of quotas that meet statistical significance conditions have been estimated for them. However, their activity is important when it comes to implementing innovations on a national scale.

\section{References}

Barra, C., \& Zotti, R. (2018). The contribution of university, private and public sector resources to Italian regional innovation system (in)efficiency. Journal of Technology Transfer, 43(2). doi:10.1007/s10961-016-9539-7.

Castillo, F., Gilless, J.K., Heiman, A., \& Zilberman, D. (2018). Time of adoption and intensity of technology transfer: an institutional analysis of offices of technology transfer in the United States. Journal of Technology Transfer, 43(1). doi:10.1007/s10961-016-9468-5.

Danieluk, B. (2010). Zastosowanie regresji logistycznej w badaniach eksperymentalnych. Psychologia Spoteczna, 5(2-3).

Diez-Vial, I., \& Montoro-Sanchez, A. (2016). How knowledge links with universities may foster innovation: the case of a science park. Technovation, 50-51. doi:10.1016/j.technovation.2015.09.001.

GUS. (2017). Rocznik statystyczny przemystu 2017. Retrieved 18.01.2019 from https://stat.gov.pl.

Koprowska-Skalska, E. (2010). Ośrodki szkoleniowo-doradcze. In K.B. Matusiak (Ed.), Ośrodki innowacji i przedsiębiorczości w Polsce. Raport 2010. Warszawa: PARP.

Local Data Bank. (2018). Retrieved 18.01.2019 from https://bdl.stat.gov.pl.

Maddala, G.S. (2006). Ekonometria. Warszawa: PWN.

Makarevich, A. (2018). Ties of survival: specialization, inter-firm ties, and firm failure in the US venture capital industry. Journal of Business Research, 86. doi:10.1016/j.jbusres.2018.02.001.

Matusiak, K.B. (2011). Ośrodki innowacji i przedsiębiorczości. In K.B. Matusiak (Ed.), Innowacje i transfer technologii. Stownik pojęć. Warszawa: PARP. Retrieved 18.01.2019 from http://www.pi.gov.pl.

OECD, \& Eurostat. (2005). Oslo manual: guidelines for collecting and interpreting innovation data, 3rd edition: The measurement of scientific and technological activities. Paris: OECD Publishing. doi:10.1787/9789264013100-en.

Pietras, P. \& Głodek, P. (2011). Finansowanie przedsięwzięć innowacyjnych w MSP. Warszawa: PARP. Retrieved 18.01.2019 from http://www.pi.gov.pl.

Rocio Vasquez-Urriago, A., Barge-Gil, A., \& Modrego Rico, A. (2016). Science and technology parks and cooperation for innovation: empirical evidence from Spain. Research Policy, 45(1). doi:10.1016/j.respol.2015.07.006.

Stanisz, A. (2007). Przystępny kurs statystyki. Modele liniowe i nieliniowe. Kraków: Statsoft.

Stokan, E., Thompson, L., \& Mahu, R.J. (2015). Testing the differential effect of business incubators on firm growth. Economic Development Quarterly, 29(4). doi:10.1177/0891242415597065. 
Świadek, A. (2011). Regionalne systemy innowacji w Polsce. Warszawa: Difin. Welfe, A. (2008). Ekonometria. Warszawa: PWE.

\section{Acknowledgements}

Author contributions: authors have given an approval to the final version of the article. Authors contributed to this work equally.

Funding: this research was undertaken as part of the project Determinants of innovation activity in enterprises in regional industry systems and was fully funded by WSB University in Poznań, Faculty of Economics in Szczecin statutory sources.

Supplementary information: authors acknowledge following people for help with the preparation of the article: dr hab. Arkadiusz Świadek.

Note: the results of this study were presented in another form, such as an abstract at Second Scientific Conference Institutions: theory and practice (June, 19-20 2018, Toruń, Poland). 


\section{Appendix}

\section{Table 1.}

Cooperation of the studied company with business support organizations in 2014-2016

\begin{tabular}{lcc}
\hline \multicolumn{1}{c}{ Business support organizations } & Quantity of companies & Percentage \\
\hline technology parks & 45 & 10.2 \\
technology incubators & 21 & 4.8 \\
academic business incubators & 11 & 2.5 \\
technology transfer offices & 18 & 4.1 \\
business angels networks & 16 & 3.6 \\
local and regional loan funds & 88 & 19.9 \\
credit guarantee funds & 90 & 20.4 \\
training and consulting centers & 153 & 34.6 \\
\hline
\end{tabular}

Source: author's own research based on survey.

Table 2.

Influence of business support organizations on expenditure on innovation activity in the Greater Poland Voivodeship in 2014-2016

\begin{tabular}{|c|c|c|c|c|c|}
\hline \multirow[b]{2}{*}{ Business support organizations } & \multirow[b]{2}{*}{$\begin{array}{l}\text { Expenditures } \\
\text { on } R \& D\end{array}$} & \multirow[b]{2}{*}{$\begin{array}{l}\text { Investment } \\
\text { on new fixed } \\
\text { assets }\end{array}$} & \multicolumn{2}{|c|}{ of which expenditures on } & \multirow[b]{2}{*}{$\begin{array}{c}\text { Expenditures } \\
\text { on computer } \\
\text { software }\end{array}$} \\
\hline & & & $\begin{array}{l}\text { buildings. } \\
\text { offices } \\
\text { and lands }\end{array}$ & $\begin{array}{c}\text { machinery } \\
\text { and technical } \\
\text { equipment }\end{array}$ & \\
\hline technology parks & $2.19^{* *}$ & - & - & $2.28^{* *}$ & $3.23^{*}$ \\
\hline technology incubators & $2.42^{* * *}$ & - & - & - & - \\
\hline academic business incubators & $8.80^{*}$ & - & - & - & - \\
\hline technology transfer offices & - & - & - & - & - \\
\hline business angels networks & - & - & - & - & - \\
\hline local and regional loan funds & $2.31^{*}$ & $1.95^{* * *}$ & - & - & - \\
\hline credit guarantee funds & - & - & - & $1.97^{* *}$ & - \\
\hline training and consulting centers & $1.89^{* *}$ & $3.77^{*}$ & $2.64^{*}$ & $2.04^{*}$ & $1.78^{*}$ \\
\hline constants & $0.33^{*}$ & $2.19^{*}$ & $0.32^{*}$ & $1.54^{*}$ & - \\
\hline chi-square & 42.08 & 30.78 & 20.97 & 22.24 & 18.85 \\
\hline $\mathrm{p}$-value & 0.0000 & 0.0000 & 0.0000 & 0.0001 & 0.0001 \\
\hline
\end{tabular}

Notes:

* - statistical significance 0.01

** — statistical significance 0.05

*** — statistical significance 0.1

Source: author's own research based on survey. 
Table 3.

Influence of business support organizations on product and process innovations in the Greater Poland Voivodeship in 2014-2016

\begin{tabular}{lrrrrr}
\hline & & Implementation & \multicolumn{2}{c}{ including: } \\
\cline { 5 - 6 } Business support organizations & $\begin{array}{c}\text { Implementation } \\
\text { of new product }\end{array}$ & $\begin{array}{c}\text { of new } \\
\text { technological } \\
\text { processes }\end{array}$ & $\begin{array}{c}\text { manufacturing } \\
\text { methods }\end{array}$ & $\begin{array}{c}\text { production- } \\
\text { related } \\
\text { systems }\end{array}$ & $\begin{array}{c}\text { support } \\
\text { systems }\end{array}$ \\
\hline technology parks & $2.30^{* *}$ & $2.93^{* *}$ & - & - & $3.40^{*}$ \\
technology incubators & - & - & - & - & $5.55^{*}$ \\
academic business incubators & - & - & - & - & - \\
technology transfer offices & - & - & $2.80^{* * *}$ & - & - \\
business angels networks & $2.34^{*}$ & $2.97^{* *}$ & $2.73^{*}$ & - & - \\
local and regional loan funds & - & $3.86^{*}$ & $2.27^{*}$ & $2.28^{*}$ & $1.70^{* * *}$ \\
credit guarantee funds & - & $3.85^{*}$ & $1.86^{* *}$ & $1.91^{*}$ & $1.61^{* * *}$ \\
training and consulting centers & $1.59^{*}$ & $1.42^{* *}$ & $0.72^{* *}$ & $0.26^{*}$ & $0.17^{*}$ \\
constants & 14.12 & 61.24 & 50.67 & 29.28 & 48.80 \\
\hline chi-square & 0.009 & 0.0000 & 0.0000 & 0.0000 & 0.0000 \\
p-value & & & &
\end{tabular}

Notes:

* - statistical significance 0.01

** - statistical significance 0.05

*** — statistical significance 0.1

Source: author's own research based on survey.

Table 4.

Influence of business support organizations on spectrum of novelty of product innovations in the Greater Poland Voivodeship in 2014-2016

\begin{tabular}{|c|c|c|c|c|}
\hline \multirow{2}{*}{ Business support organizations } & \multicolumn{4}{|c|}{ Novelty for } \\
\hline & enterprise & market & country & world \\
\hline technology parks & - & - & $2.31^{* *}$ & - \\
\hline technology incubators & - & - & - & - \\
\hline academic business incubators & - & - & $4.40^{* *}$ & - \\
\hline technology transfer offices & - & - & - & - \\
\hline business angels networks & - & - & - & - \\
\hline local and regional loan funds & $1.90^{* *}$ & - & - & - \\
\hline credit guarantee funds & $1.71^{* * *}$ & - & - & - \\
\hline training and consulting centers & $1.60^{* *}$ & - & - & - \\
\hline constants & 0.35 & - & $0.16^{*}$ & - \\
\hline chi-square & 27.37 & - & 10.29 & - \\
\hline $\mathrm{p}$-value & 0.0000 & - & 0.0059 & - \\
\hline
\end{tabular}

Notes:

* _ statistical significance 0.01

** — statistical significance 0.05

*** _ statistical significance 0.1

Source: author's own research based on survey. 
Table 5 .

Influence of business support organizations on spectrum of novelty of process innovations in the Greater Poland Voivodeship in 2014-2016

\begin{tabular}{|c|c|c|c|c|}
\hline \multirow{2}{*}{ Business support organizations } & \multicolumn{4}{|c|}{ Novelty for } \\
\hline & enterprise & market & country & world \\
\hline technology parks & - & - & - & - \\
\hline technology incubators & - & - & - & - \\
\hline academic business incubators & - & - & $4.41^{* *}$ & - \\
\hline technology transfer offices & - & - & $4.00^{* *}$ & - \\
\hline business angels networks & - & - & - & - \\
\hline local and regional loan funds & $2.05^{* *}$ & - & - & - \\
\hline credit guarantee funds & $2.23^{*}$ & - & $0.34^{* *}$ & - \\
\hline training and consulting centers & $2.47^{*}$ & - & - & - \\
\hline constants & $0.55^{*}$ & - & $0.13^{*}$ & - \\
\hline chi-square & 54.83 & - & 15.29 & - \\
\hline p-value & 0.0000 & - & 0.0016 & - \\
\hline
\end{tabular}

Notes:

* — statistical significance 0.01

** — statistical significance 0.05

*** — statistical significance 0.1

Source: author's own research based on survey. 
